\title{
Global analysis of radiative forcing from fire-induced shortwave albedo change
}

\author{
G. López-Saldaña, I. Bistinas, and J. M. C. Pereira \\ Centro de Estudos Florestais, Instituto Superior de Agronomia, Universidade de Lisboa, Tapada da Ajuda, \\ 1349-017 Lisboa, Portugal \\ Correspondence to: G. López-Saldaña (gerardolopez@isa.utl.pt)
}

Received: 30 April 2014 - Published in Biogeosciences Discuss.: 28 May 2014

Revised: 13 November 2014 - Accepted: 1 December - Published: 29 January 2015

\begin{abstract}
Land surface albedo, a key parameter to derive Earth's surface energy balance, is used in the parameterization of numerical weather prediction, climate monitoring and climate change impact assessments. Changes in albedo due to fire have not been fully investigated on a continental and global scale. The main goal of this study, therefore, is to quantify the changes in instantaneous shortwave albedo produced by biomass burning activities and their associated radiative forcing.

The study relies on the MODerate-resolution Imaging Spectroradiometer (MODIS) MCD64A1 burned-area product to create an annual composite of areas affected by fire and the MCD43C2 bidirectional reflectance distribution function (BRDF) albedo snow-free product to compute a bihemispherical reflectance time series. The approximate day of burning is used to calculate the instantaneous change in shortwave albedo. Using the corresponding National Centers for Environmental Prediction (NCEP) monthly mean downward solar radiation flux at the surface, the global radiative forcing associated with fire was computed.

The analysis reveals a mean decrease in shortwave albedo of $-0.014(1 \sigma=0.017)$, causing a mean positive radiative forcing of $3.99 \mathrm{Wm}^{-2}(1 \sigma=4.89)$ over the 2002-20012 time period in areas affected by fire. The greatest drop in mean shortwave albedo change occurs in 2002, which corresponds to the highest total area burned (378 Mha) observed in the same year and produces the highest mean radiative forcing $\left(4.5 \mathrm{Wm}^{-2}\right)$.

Africa is the main contributor in terms of burned area, but forests globally give the highest radiative forcing per unit area and thus give detectable changes in shortwave albedo. The global mean radiative forcing for the whole period stud-
\end{abstract}

ied $\left(\sim 0.0275 \mathrm{Wm}^{-2}\right)$ shows that the contribution of fires to the Earth system is not insignificant.

\section{Introduction}

Land surface conditions have a strong impact on the Earth's system energy balance through changes in land surface albedo that induce a radiative forcing by perturbing the shortwave radiation budget (Ramaswamy et al., 2001). The total solar incoming radiation has a mean strength of $\sim 1366 \mathrm{Wm}^{-2}$ ("solar constant") and has an irregular cycle of about 11 years, causing a variation of $\pm 0.5 \mathrm{Wm}^{-2}$ (Gray, 2010). Since, on average, the Earth absorbs energy at the rate of $(1-A) I_{\mathrm{TS}} / 4$ (Gray, 2010), where $A$ is the Earth's albedo and $I_{\mathrm{TS}}$ the total solar irradiance, taking $I_{\mathrm{TS}}=1366 \mathrm{Wm}^{-2}$ and a mean albedo of the Earth $A=0.3$ (Prentice at al., 2012), the solar power available to the whole Earth system is $239.05 \mathrm{Wm}^{-2}$. The importance of quantifying changes in albedo arises here. The global mean concentration of $\mathrm{CO}_{2}$ in 2005 was $379 \mathrm{ppm}$, leading to a radiative forcing of $+1.66 \mathrm{Wm}^{-2}(1 \sigma=0.17)$ (Forster et al., 2007), while that of changing the planetary albedo by as little as 0.01 can produce a change in the radiation balance of $2.39 \mathrm{Wm}^{-2}$, revealing that even small changes in albedo can have a substantial impact on the Earth system.

Fire has a strong influence on climate due to the release of atmospheric aerosols and gases and can modify surface albedo by the removal of vegetation and deposition of ash and charcoal (Bowman, 2009). Earlier studies aimed to quantify the impact of fires on the land surface albedo. Govaerts et al. (2002) analysed a Meteosat albedo time series for 1996 in 
Northern Hemisphere Africa and, using fire-induced albedo perturbation probabilities, estimated that fires are responsible for a relative albedo decrease as large as $25 \%$. Jin and Roy (2005) used MODIS (MODerate-resolution Imaging Spectroradiometer) data to estimate a mean 2003 instantaneous shortwave albedo change of -0.024 over all the burned areas in the Australian tropical savanna, which exerted a shortwave surface radiative forcing of $6.23 \mathrm{Wm}^{-2}$. Several studies have been carried out in the boreal area: Jin et al. (2012a) analysed the sensitivity of spring albedo to the MODIS-derived difference Normalized Burn Ratio (dNBR), while Jin et al. (2012b) found a fire-induced surface shortwave forcing (SSF) integrated over an annual cycle of $-4.1 \mathrm{Wm}^{-2}$ between southern and northern boreal regions. However, studies over longer time periods on a global scale are needed to improve the understanding of the influence of fire on the Earth system as an agent of land surface alteration and its impact on the energy balance.

No earlier studies have attempted to quantify the impact of fire on shortwave albedo on a global scale; therefore, the main goal of this study is to quantify the "instantaneous" shortwave albedo change in areas affected by fire and the corresponding radiative forcing at the surface. The radiative forcing contributed by aerosols produced by fires is not considered, since the scope of the study is to investigate exclusively the impact of fires at the surface. We derived an albedo time series and then calculated the difference in the pre- and post-fire shortwave albedo only in areas affected by fire for the 200-2012 time period. The radiative forcing exerted by the changes in albedo was calculated using the total solar incoming radiation.

\section{Data}

\subsection{Albedo time series generation and burned-area identification}

The shortwave albedo time series was generated using the MODIS Collection 5 bidirectional reflectance distribution function (BRDF) albedo snow-free quality product (MCD43C2) (Schaaf et al., 2002). It is produced on a 16-day basis with an 8 -day overlap projected to a $0.05^{\circ}$ latitudelongitude climate modelling grid (CMG). The product models the surface anisotropy using all high-quality, cloud-free, snow-free and atmospherically corrected land surface reflectance obtained within a 16-day time period. When there are more than seven of these observations, a so-called full model inversion is attempted to retrieve the BRDF parameters based on the RossThickLiSparse-Reciprocal BRDF model (Lucht et al., 2000). If there are only three to six of the aforementioned observations over the 16-day time period, a backup algorithm is used; it is based on an archetypal BRDF model parameter which is defined with respect to 25 global land cover classes and from historical high-quality retrievals
(Ju et al., 2010). Data for 11 years, 2002-2012, were downloaded from the Land Processes Distributes Active Archive Center (LP DAAC) data pool.

In order to use only the highest-quality data, the BRDF_Quality science data set provided with the MCD43C2 was analysed. Only pixels with the best quality ( $75 \%$ or more with best full inversions) and good quality ( $75 \%$ or more with full inversions) were kept for further processing. The global bihemispherical reflectance $\left(\alpha_{\mathrm{BHR}}\right)$ under isotropic illumination, also designated white-sky albedo, for every 16day time period was computed using

$\alpha_{\mathrm{BHR}}(\lambda)=f_{\text {iso }}(\lambda) g_{\text {iso }}+f_{\mathrm{vol}}(\lambda) g_{\mathrm{vol}}+f_{\text {geo }}(\lambda) g_{\mathrm{geo}}$,

where $f_{\text {iso }}, f_{\text {vol }}$ and $f_{\text {geo }}$ are the three BRDF model parameters: isotropic, volumetric and geometric. The integrated coefficients have the following values: $g_{\text {iso }}=1.0 ; g_{\mathrm{vol}}=$ 0.189184 ; and $g_{\text {geo }}=-1.377622$.

Some areas can show gaps caused by a lack of high-quality data and by the screening based on the BRDF_ Quality flag. A linear temporal interpolation was computed to create a synthetic, temporally and spatially continuous shortwave albedo product. The interpolation was performed on a yearly basis but taking into account 1 month before and after the calendar year to be able to fill gaps at the very beginning or at the very end of the year. The final product consists of a gap-free 16-day (with an 8-day overlap) snow-free broadband shortwave albedo time series with a $0.05^{\circ}$ spatial resolution for 2002-2012.

\subsection{Burned-area identification}

The areas affected by fire each year were derived using the MODIS Collection 5.1 Direct Broadcast Monthly Burned Area Product (MCD64A1) (Gilgio et al., 2009). The product identifies post-fire burned areas using daily $500 \mathrm{~m}$ surface reflectance coupled with $1 \mathrm{~km}$ MODIS active fire observations. Twelve years of data were downloaded from (MCD64A1 burned-area product) spanning the years 2002 to 2012. The spatial resolution of the product is $500 \mathrm{~m}$ and is generated on a monthly basis. It was necessary to perform a spatial aggregation on the monthly data sets to $0.05^{\circ}$ to match the CMG spatial resolution. The proportion of the CMG pixel that was affected by fire was calculated, thus giving a fractional burn area estimate. When more than one date was found inside a CMG pixel, the mode of the day of burning was set as the day of burning. The annual burned-area data set was generated selecting the approximate day of burned from the monthly data sets. When more than one day was found the earliest date was selected.

\subsection{Land-use-land-cover (LULC) maps}

The MODIS Collection 5.1 Land Cover Type Yearly L3 Global 0.05Deg CMG (MCD12C1) (Friedl et al., 2010) is produced at $0.05^{\circ}$ spatial resolution and provides the 
dominant land cover type and the sub-grid frequency land cover class distribution within each $0.05^{\circ}$ cell.

In order to analyse major biomes, an aggregation of the land cover classes was performed. For every year from 2002 to 2012, the following groups were created: (1) all forest classes (evergreen needleleaf forest, evergreen broadleaf forest, deciduous needleleaf forest, deciduous broadleaf forest, mixed forests) were aggregated into a single "Forest" class; (2) croplands and a cropland/natural vegetation mosaic was aggregated into the "Croplands" class; (3) closed shrubland, open shrublands, woody savannas, savannas, grasslands and permanent wetlands were aggregated into the "non-forest" class. The aggregation takes into account the confidence level; the "majority land cover type 2 " was only used when confidence was below $60 \%$.

Additionally to the analysis per land cover, an analysis per continent was be performed.

\subsection{Downward shortwave solar radiation flux at the surface}

The National Centers for Environmental Prediction and the National Center for Atmospheric Research (NCEP-NCAR) Reanalysis 1 (Kalnay et al., 1996) provides the monthly mean downward solar radiation flux (dswrf) at the surface in $\mathrm{Wm}^{-2}$ in $1.8^{\circ}$ by $1.8^{\circ}$ grid cells from 1948 to 2013 . The full reanalysis data set was obtained from NCEP/NCAR dswrf at the surface. A temporal subset was extracted to obtain 12 years of monthly dswrf from 2002-2012.

\section{Quantification of albedo change and associated radiative forcing}

\subsection{Method description}

For every pixel identified as affected by fire within a calendar year, the change in broadband shortwave albedo is calculated as

$\Delta A_{\text {fire }}=A_{\text {post }}-A_{\text {pre }}$,

where $\Delta A_{\text {fire }}$ is the "instantaneous" land surface shortwave albedo change when subtracting the pre-fire albedo $\left(A_{\text {pre }}\right)$ from the post-fire albedo $\left(A_{\text {post }}\right)$.

The selection of the dates to compute the change in albedo is not straightforward, and several factors must be taken into account.

First, the albedo time series was computed using the BRDF model parameters, and these parameters were derived fitting a BRDF model using all high-quality observations within a 16-day time period. The assumption is that, even when there may be day-to-day changes in land surface condition, these high-quality observations have normally distributed random noise and can describe the BRDF (Lucht and Lewis, 2000). However, fire affects vegetated areas, which generally are very reflective in the near-infrared and which, after a burning event, show a decrease in reflectance due to vegetation loss and deposition of charcoal and ash (Pereira, 1999; Stroppiana, 2002). Additionally, some fire events may last more than 1 day in several areas around the globe (Chuvieco et al., 2008). Therefore, the 16-day time periods adjacent to the approximate day of burned might have used mixed observations, burned and non-burned, to fit the BRDF model, resulting in a smooth transition from the pre-fire to post-fire albedo rather than a sharp change.

Second, there are uncertainties regarding the day of burning. The MCD64A1 product relies on both daily surface reflectance and daily fire masks. However, a minimum of approximately 10 days of cloud-free observations before and after to accommodate the moving windows employed in the change-detection process are needed; a lack of data due to clouds or coverage gaps doubles the number of days required (Gilgio et al., 2009). Additionally, the quality assessment (QA) scientific data set (SDS) masks surface reflectance pixels when an active fire is detected, which increases the temporal uncertainty in the identification of the day of burned.

Given these two factors, an analysis to quantify the length of the window was carried out, centred on the approximate day of burning, which is needed to compute the change in albedo was carried out. The result is that, on a global scale, it is best to use a 32-day window. The $A_{\text {pre }}$ date was set, identifying the maximum albedo previous to the fire occurrence, while the $A_{\text {post }}$ date is the minimum albedo value after the fire.

Ramaswamy et al. (2001) define radiative forcing as "the change in net (down minus up) irradiance (solar plus longwave; in $\mathrm{Wm}^{-2}$ )". In this study, we do not consider longwave forcing. Once the change in albedo $\Delta A_{\text {fire }}$ was computed, the shortwave radiative forcing at the surface $\Delta F_{0}$ exerted by changes in shortwave albedo due only to fire is estimated as

$$
\Delta F_{0}=-\operatorname{dswrf}_{0}^{\downarrow} \Delta A_{\text {fire }},
$$

where $-\mathrm{dswrf}_{0}^{\downarrow}$ is the monthly mean downward solar radiation flux (dswrf) at the surface in $\mathrm{Wm}^{-2}$; the subscript (0) denotes the quantity at the surface.

\section{Results}

The global spatial distribution of mean radiative forcing caused by "instantaneous" shortwave albedo changes on areas affected by fires is depicted in Fig. 1. Most fires occur in tropical and subtropical environments. High values of radiative forcing in those areas, e.g. greater that $5 \mathrm{Wm}^{-2}$ in those areas, shown by dark red shading, might suggest frequent intense fire occurrence like in South Sudan, Angola and northern Australia, whereas low forcing in dark blue shades, such as the big cluster in the Ukraine and the southwest corner 


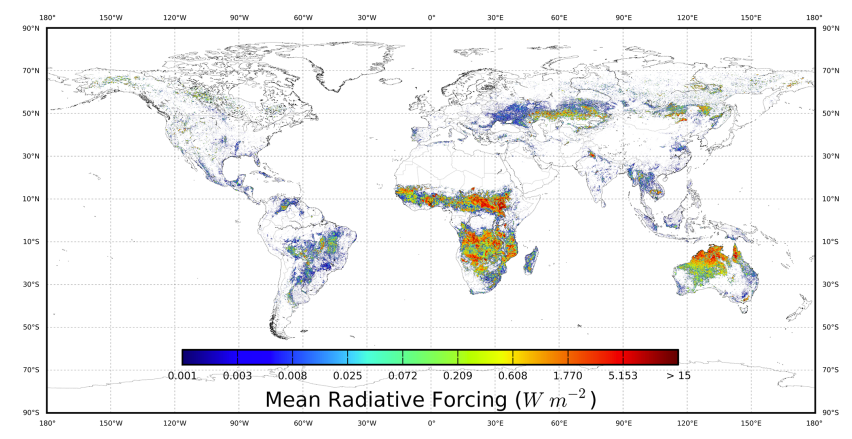

Figure 1. Global mean radiative forcing caused by "instantaneous" shortwave albedo changes in areas affected by fires during 20022012. The values were normalized using a logarithmic scale.

of the Russian Federation, is related to frequent non-intense fires.

Overall, the trend in burned area for the whole studied period is negative; however, the albedo change and the radiative forcing show no significant trend (Fig. 2). The mean albedo changes, considering the change between post-fire shortwave albedo minus the pre-fire value, have a slight annual decrease matching the trend of the total annual area burned. Ultimately, a fire event will decrease the shortwave albedo, resulting in a positive radiative forcing in return. Figs. 5 and 6 show, for the Sahel and Australia, the approximate day of burning (DoB), instantaneous shortwave albedo change, the relative albedo change and the associated radiative forcing. Areas in red tones indicate a large change, and areas in blue shading indicates a small difference in the albedo changes. Nevertheless, the consistent decrease in burned area did not produce a significant decrease in albedo changes; this could be explained due to alterations in fire intensity.

The global mean change in albedo is $-0.014(\sigma=0.017)$, causing a mean positive radiative forcing of $3.99 \mathrm{Wm}^{-2}(\sigma=$ 4.89) on a global mean annual burned area of $349.48 \mathrm{Mha}$ ( $\sigma=21.81 \mathrm{Mha}$ ) during the 2002-2012 time period.

In order to quantify the global or regional impact, it is necessary to normalize the forcing by the proportion of the total area burned to the total surface. Given $r=6371007.181 \mathrm{~m}$ as the radius of the idealized sphere representing the Earth, the total global surface is $4 \pi r^{2}, \sim 510.07 \mathrm{Mkm}^{2}$. Assuming that land makes up $30 \%$ of the planet and given the mean radiative forcing in areas where fire occurred during 20022012 is $3.99 \mathrm{Wm}^{-2}$, the global mean forcing only on land is only $1.197 \mathrm{Wm}^{-2}$. The mean annual global area affected by fires during the 11 years comprising the study period is $349.48 \mathrm{Mha}$ or $3.4948 \mathrm{Mkm}^{2}, \sim 0.69 \%$ of the Earth's surface. Using again the mean radiative forcing in areas where fire occurred during 2002-2012 $\left(3.99 \mathrm{Wm}^{-2}\right)$ and multiplying this by the proportion of area affected by fire, the global mean radiative forcing is $0.0275 \mathrm{Wm}^{-2}$. When performing the same calculation on a regional scale, for instance, Australia, the mean radiative forcing is $5.71 \mathrm{Wm}^{-2}$ and the mean
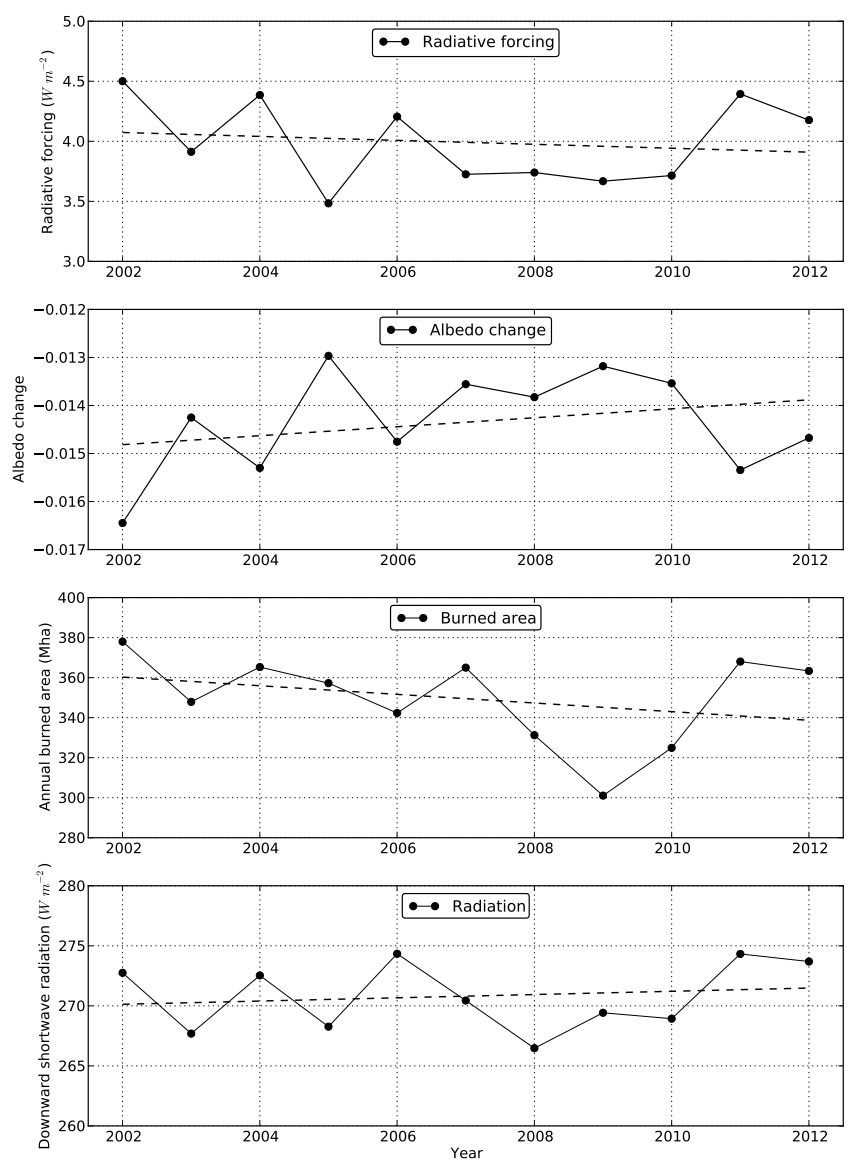

Figure 2. Temporal changes in the annual global radiative forcing induced by fires and albedo change spanning the years 2002 to 2012. Bottom plots show the total annual burned area and the downward shortwave radiation fluxes at the surface. The dashed lines depict linear trends, where changes of rate per year are, for radiative forcing, $-0.016 \mathrm{Wm}^{-2}$; albedo change is $9.33 \mathrm{e}-05$; the burned area is $-2.15 \mathrm{Mha}$; and downward shortwave incoming radiation is $0.14 \mathrm{Wm}^{-2}$.

area burned is $0.502 \mathrm{Mkm}^{2}$, representing the $6.53 \%$ of the Australian territory. Therefore, the mean radiative forcing for Australia is $0.373 \mathrm{Wm}^{-2}$, an order of magnitude higher than the global number.

\subsection{Interannual variability and land cover affected}

On the global scale, the highest mean radiative forcing occurs in forested areas in 2003, in 2006 and in 2010. Croplands and non-forests have a stable interannual cycle, with the exception of 2002 and 2003, the years with the highest mean values (Fig. 4). The main discrepancies between area burned and radiative forcing occur in the period of 2005-2007, where intermediate-high area burned values are associated with the lowest values of radiative forcing in 2005 and 2007 and a high abrupt peak in 2006. 
The greatest drop in mean shortwave albedo change occurs in 2002, which corresponds to the highest total area burned (3.78 Mha) observed in the same year and produces the highest mean radiative forcing $\left(4.5 \mathrm{Wm}^{-2}\right)$ (Fig. 2). The lowest shortwave albedo change value in 2005 is not associated with low burned area values and similarly the lowest and very abrupt drop of area burned in 2009 does not produce the lowest albedo change and radiative forcing (Fig. 2).

Most fires occur in the Sahel (Fig. 5) and the Australian savannas (Fig. 6), corresponding to an average of up to $89 \%$ of the total global area burned, whereas the highest radiative forcing per unit area is located in the forests of Australia in 2003 and 2006, Europe in 2010 and Asia in 2002, with mean continental values of $15.43,15.26,13.98$ and $8.81 \mathrm{Wm}^{-2}$, respectively (Fig. 3). In croplands, Asia shows the greatest oscillations, with a minimum of $2.11 \mathrm{Wm}^{-2}$ in 2004 and a maximum of $6.1 \mathrm{Wm}^{-2}$ in 2008 (Fig. 3). The rest of the continents show a low variability in cropland areas, with the exception of Australia in 2003 showing a steep peak of $6.54 \mathrm{Wm}^{-2}$. In non-forests, the highest radiative forcing is in North America in 2004, in Europe in 2007 and in Asia in 2002 and 2010. High oscillations are also observed in Australia, with an abrupt drop in 2010, contrasting with the very stable interannual cycle of Africa. Figure 7 shows the temporal evolution of burned area over northern Africa and Australia, showing opposite behaviours. Whilst in northern Africa the burned area tends to decrease and there is no significant trend in the associated radiative forcing, in Australia, the burned area over the 11-year time period shows a positive trend associated with a negative trend in the corresponding radiative forcing; this suggests more areas affected by fire but not necessarily associated with high burn severity.

\section{Discussion and conclusions}

We have presented a study to quantify the temporal evolution of fire-induced albedo changes and the continental and global annual mean forcing estimations. We used the radiative forcing here as a measure to quantify the influence in and contribution of fire to the Earth's energy balance and showed that fired caused a consistent decrease in the land surface shortwave albedo, leading to a positive radiative forcing.

\subsection{Extreme events}

Continental Europe includes Russian territories and has as eastern borders the Ural Mountains, the Ural River and the Caucasus Mountains, as well as the shore line of the Caspian Sea. Therefore, the anomalous fire events in July 2010 around Moscow are included for the European continent. On an annual basis, in Russia, 90-95\% of burned areas are located in the Asian part of Russia, with the majority $(59.3 \%)$ being forests, with the exception of the extreme event of 2010 (Shvidenko et al., 2011). The abrupt (a)

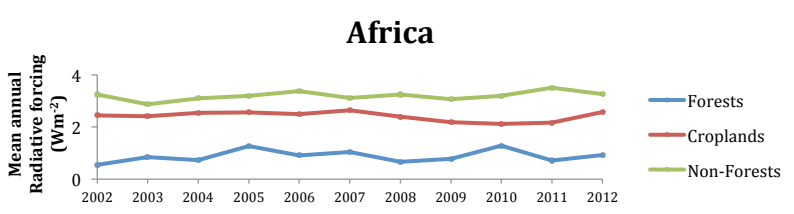

(b)

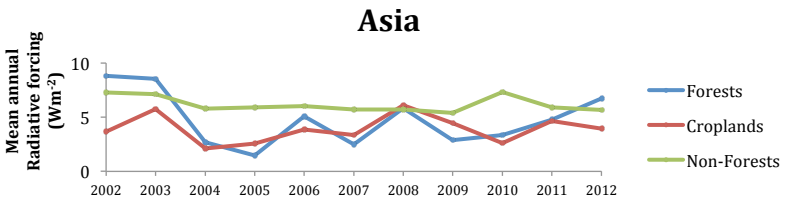

(c)

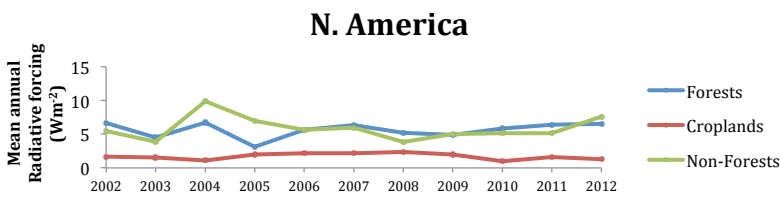

(d)

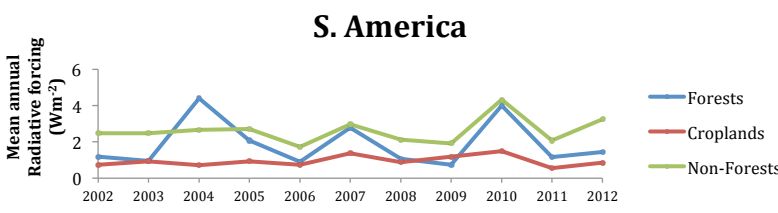

(e)

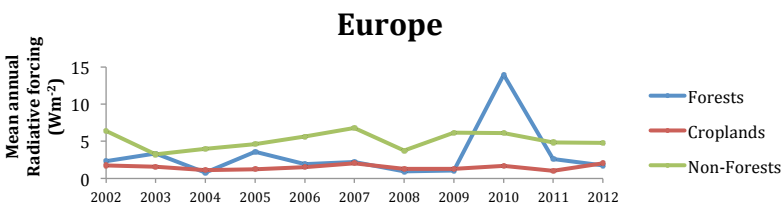

(f)

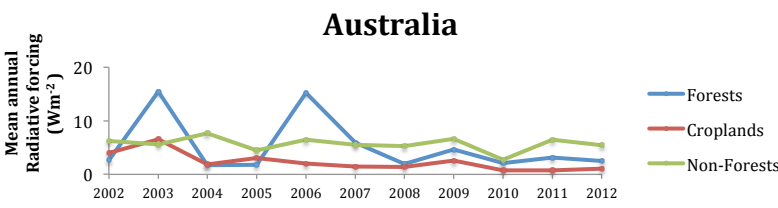

Figure 3. The mean annual radiative forcing per land cover and continent (a-f).

peak in 2010 in Fig. 3e corresponds to that event exactly, with a mean annual value for forests in continental Europe of $13.98 \mathrm{Wm}^{-2}$. The mean continental value is more realistic when compared to the massive maximum number of $167 \mathrm{Wm}^{-2}$ for the same event, including aerosols in smoky conditions, found in the literature (Chubarova et al., 2012).

Similar extreme events can be observed in Fig. $3 f$ in 2003 and 2006 in Australia, depicting the eastern Victorian alpine fires, which burned 1.3 Mha in 2003, and the Grampians fire in Victoria in 2006 that burned 184000 ha. A plausible explanation is that a weak to moderate El Niño event had a very strong impact in Australia, causing the major 2002-2003 drought and rainfall deficiencies over the period March 2002 to January 2003 (Australian Government, 2014). Fires affected eastern New South Wales (NSW), Canberra, and the mountainous areas of southeast NSW and forested areas in eastern Victoria as show in Fig. 6. A radiative forcing above 
(a)

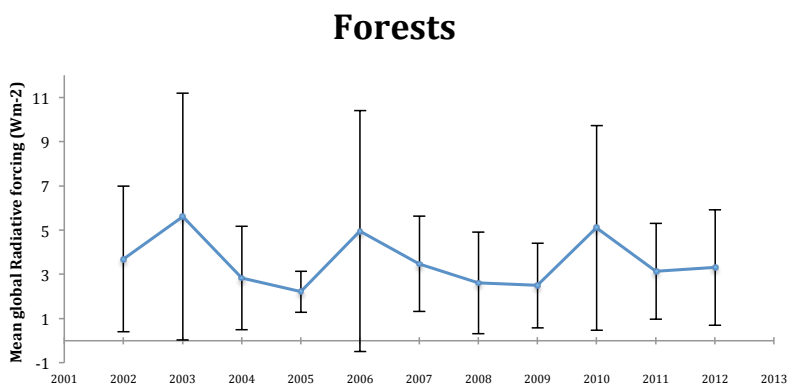

(b)

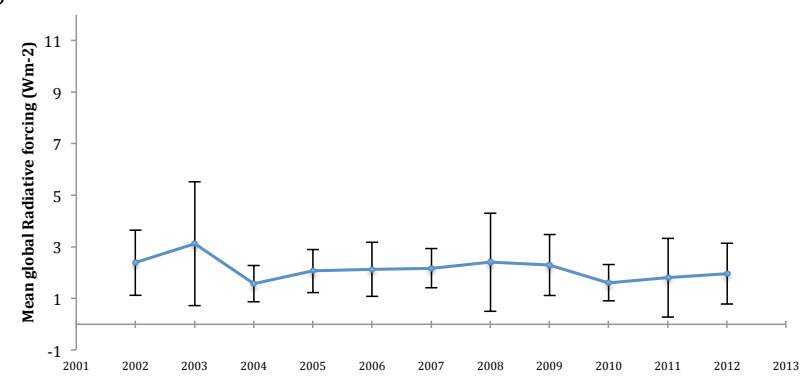

(c)

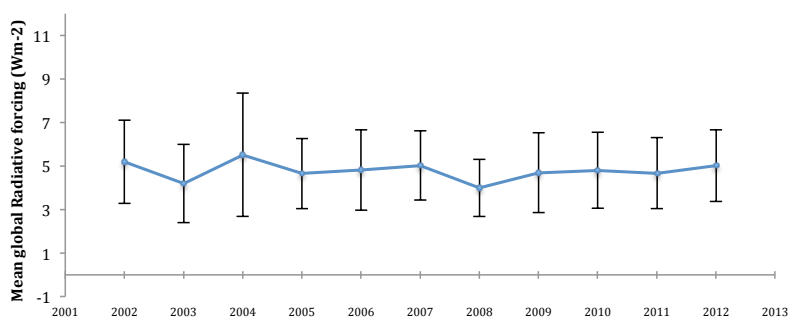

Figure 4. The mean annual radiative forcing per land cover $(\mathbf{a}-\mathbf{c})$ in $\mathrm{Wm}^{-2}$.

$25 \mathrm{Wm}^{-2}$ over northeast Victoria and the Great Dividing Range in the Kosciuszko National Park in southern NSW, mainly to a large shortwave albedo decrease due to forest fires, is shown in Fig. 6. Broadly, forest has a low shortwave albedo of $\sim 0.3$ that varies with the viewing and illumination conditions (Liang, 2000). Given the extraordinary circumstances during the 2002-2003 drought in Australia, the forest fires dramatically altered the albedo, by a relative change of up to $60 \%$ in some areas (Fig. 6) during the Austral summer (pick of incoming radiation); nevertheless, changes due to seasonality, e.g. vegetation senescence that affects surface reflectivity, were not taken into account, and a contribution of the decrease in albedo in the Australian summer might be due to these non-fire-related changes.

In Fig. 3b, the highest value of radiative forcing occurs in 2003, when the massive boreal fires in western Siberia burned over 20 Mha and were some of the largest forest fires on record (Sheng et al., 2004). Croplands and non-forests follow the west Siberian event of 2003, showing the highest mean radiative forcing value of all cropland areas (Fig. 3b).
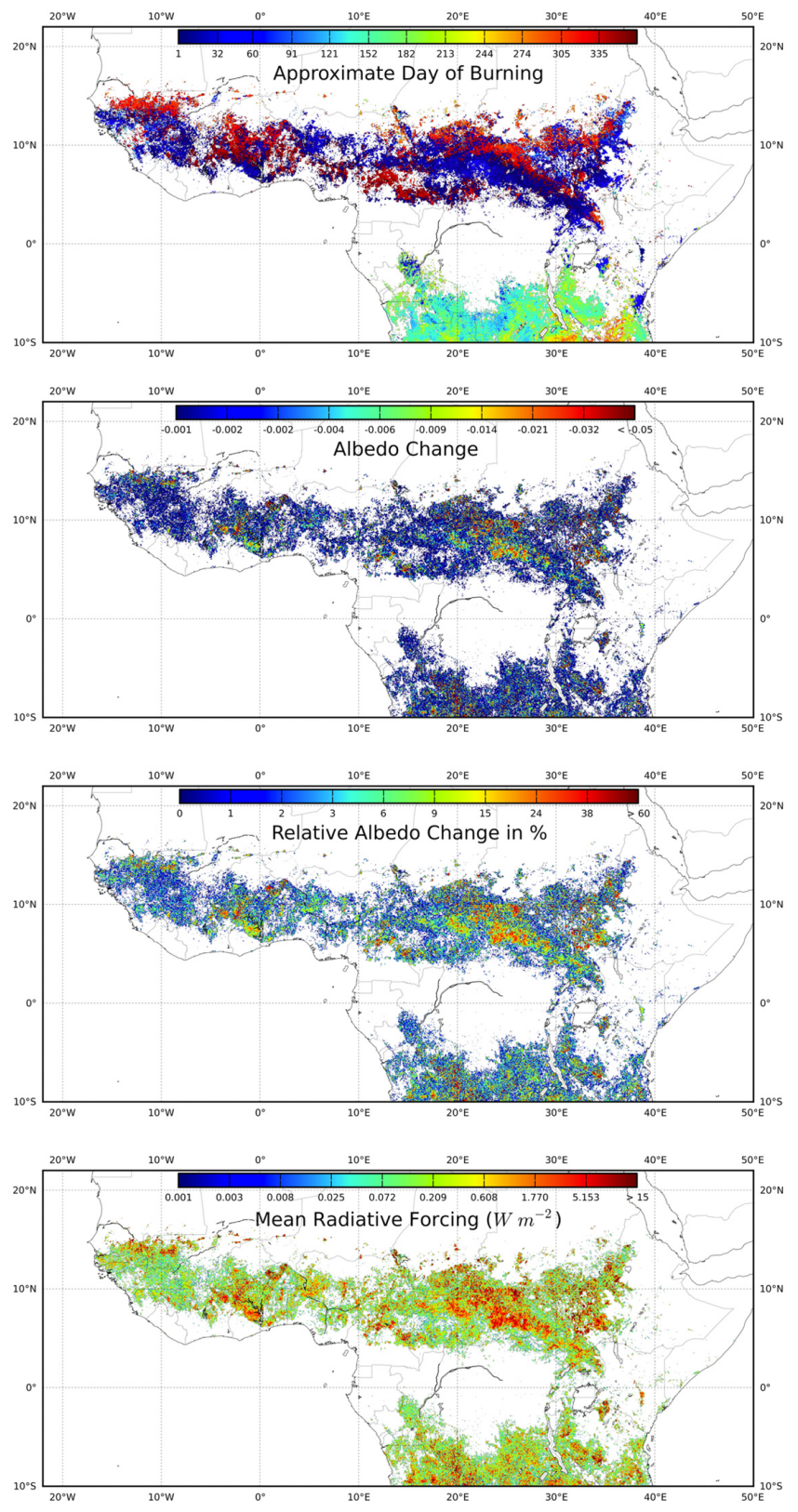

Figure 5. The approximate day of burning; the "instantaneous" shortwave albedo change in areas affected by fire; the relative change in albedo in \%; and the associated radiative forcing in $\mathrm{Wm}^{-2}$ is shown for the Sahel during 2003.

In North America in 2004, the highest continental value of mean annual radiative forcing occurs in non-forests $\left(9.89 \mathrm{Wm}^{-2}\right)$. The summer of 2004 was an extensive fire season in Alaska and western Canada, with the majority of the area burned being grasslands (including shrublands) and forests (Turquety et al., 2007).

In South America, the 3-year intervals of increased radiative forcing might be associated with teleconnections causing extensive droughts, as in 2010 (Lewis et al., 2011), that 

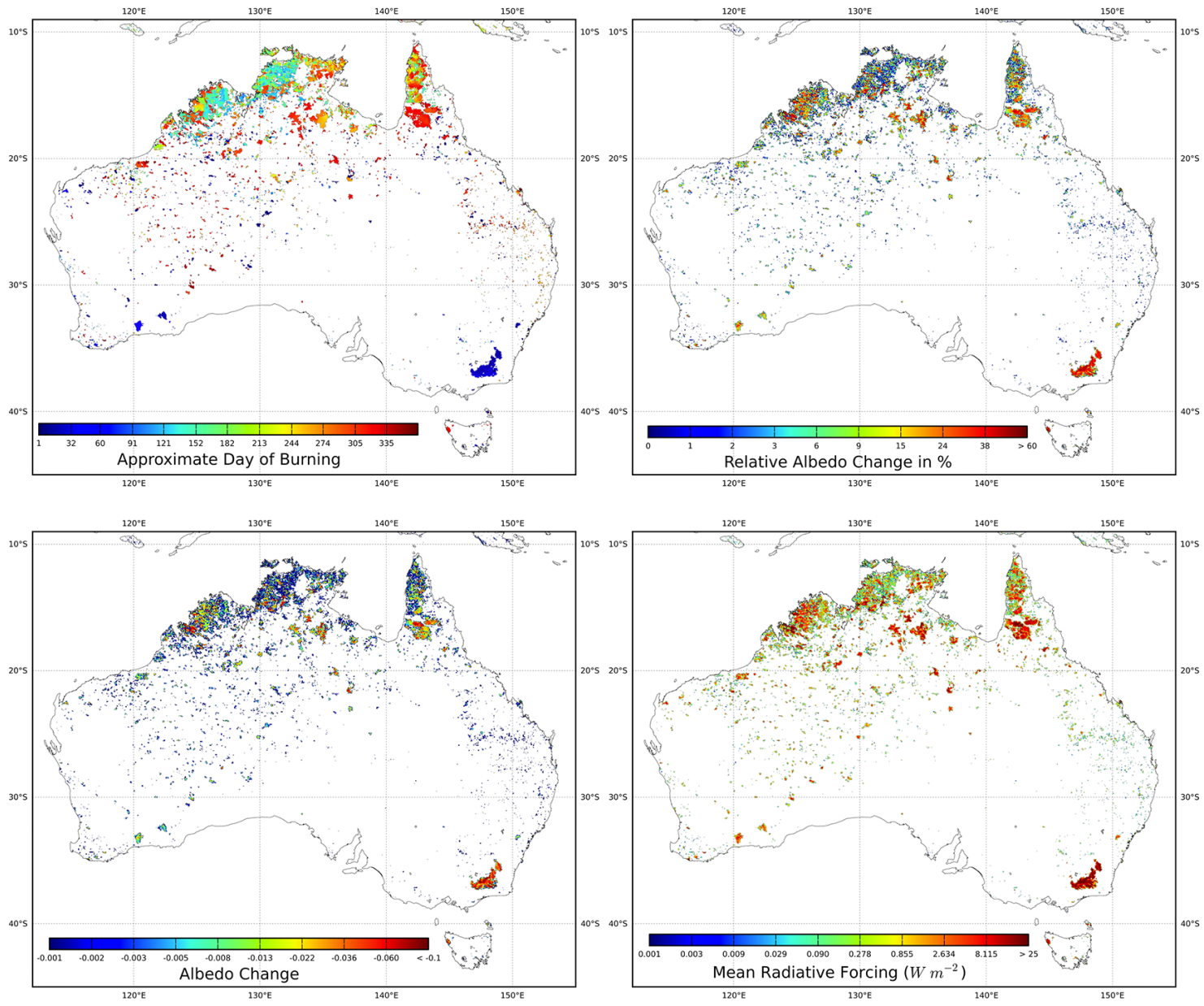

Figure 6. The approximate day of burning; the "instantaneous" shortwave albedo change in areas affected by fire; the relative albedo change in \%; and the associated radiative forcing in $\mathrm{Wm}^{-2}$ is shown for Australia during 2003.
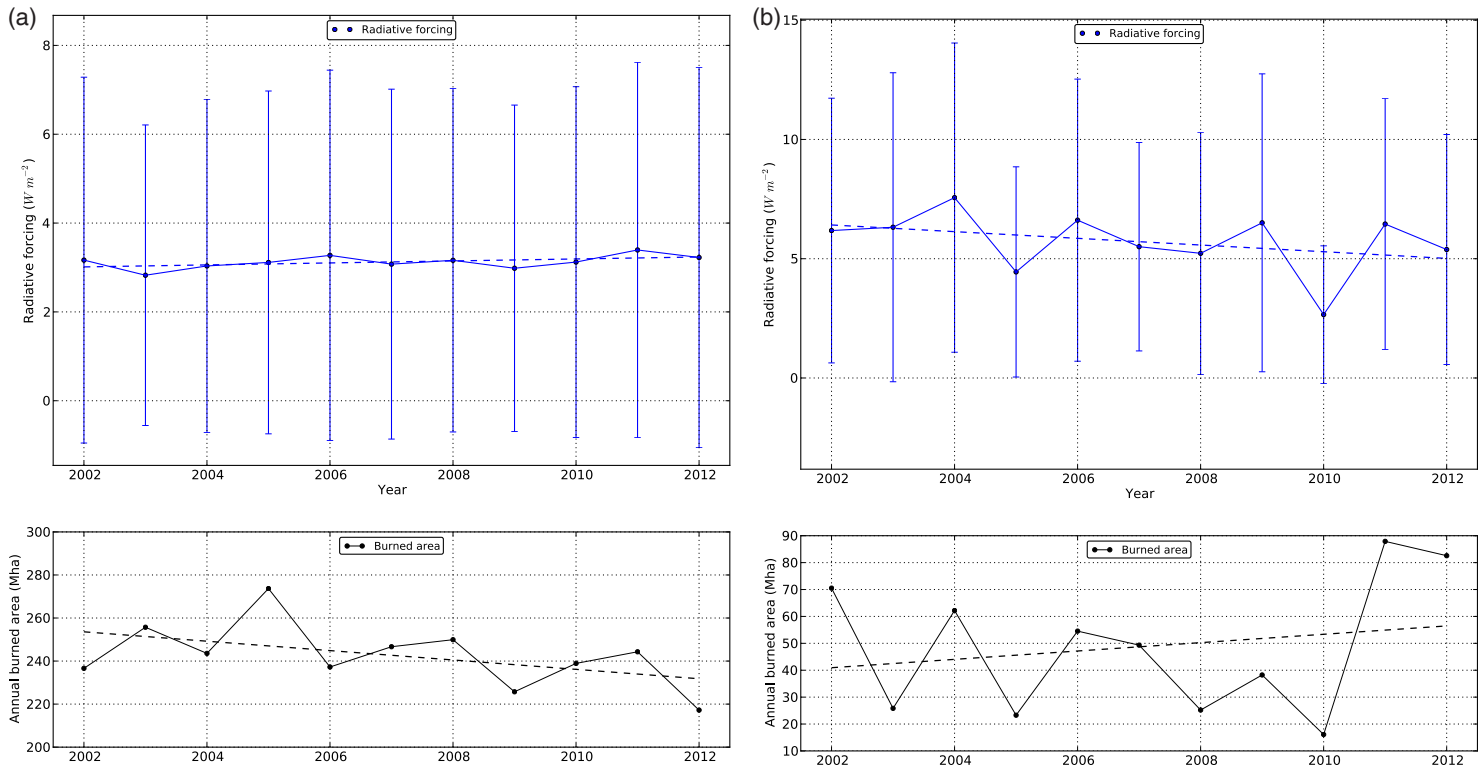

Figure 7. Temporal evolution of the radiative forcing and burned areas. Panel (a) shows the profiles for Africa, panel (b) for Australia. 
increase fire incidence in forests and savannas, but it may also be associated with anthropogenic activities (Aragão and Shimabukuro, 2010).

\subsection{Concluding remarks}

Changes in shortwave albedo are not the only source of radiative forcing when fires affect the land surface. According to the Intergovernmental Panel on Climate Change (IPCC) Fourth Assessment Report, biomass burning accounts for $75 \%$ of the direct radiative forcing from organic aerosols, and it is estimated at $-0.5 \pm 0.5 \mathrm{Wm}^{-2}$ for the period of 1750-2005 (Forster et al., 2007). In the tropics, where incident solar radiation is larger than at higher latitudes, it can enhance the radiative effect from aerosols (Holben et al., 2001). Ross et al. (1998) found a radiative forcing of about $-15 \pm 5 \mathrm{Wm}^{-2}$ during the 1995 Amazon fire season. Total black carbon emissions from biomass burning $\left(3.3 \mathrm{TgC}^{-1}\right)$ represent $40 \%$ of the total black carbon emissions, with an additional $4.6 \mathrm{TgC} \mathrm{yr}^{-1}$ contributed by fossil fuel and biofuel combustion (Bond et al., 2004). Although the overall radiative forcing of smoke aerosol particles is negative, black carbon can produce positive radiative forcing. The global radiative forcing of total black carbon was estimated at $+0.2 \mathrm{Wm}^{-2}$ in the IPCC Third Assessment Report (Ramaswamy et al., 2001) and $0.55 \mathrm{Wm}^{-2}$ in the IPCC Fourth Assessment Report (Forster et al., 2007).

A global mean radiative forcing estimation of $0.0275 \mathrm{Wm}^{-2}$ quantifies the contribution of fire to the Earth's system, in which forest fires show the most dramatic impact per area unit. Large extreme events can be detected on an annual basis and show abrupt changes in shortwave albedo and its associated radiative forcing. Although the fire incidence in Africa is the highest, with little interannual oscillations, the biggest changes in annual radiative forcing are caused by the extreme fire events in Australia, Europe and North America.

Anomalous fire events in continental Australia along with the boreal forests drive the global annual extremes of mean radiative forcing and show an excellent opportunity for future research efforts in that field.

Acknowledgements. The research leading to these results has received funding from the European Community's Seventh Framework Programme (FP7 2007-2013) under grant agreement no. 238366. For all our colleagues at LDRAG, thank you for your support. Duarte Oom: SMA\&D\&N. Haifa and Dominik, Gerannis loves you.

Edited by: A. J. Dolman

\section{References}

Aragão, L. E. O. C. and Shimabukuro, Y. E.: The incidence of fire in Amazonian forests with implications for REDD, Science, 328, 1275-1278, 2010.

Australian Government: http://www.bom.gov.au/climate/enso/ enlist/, last access: 30 April 2014.

Boisier, J. P., de Noblet-Ducoudré, N., and Ciais, P.: Inferring past land use-induced changes in surface albedo from satellite observations: a useful tool to evaluate model simulations, Biogeosciences, 10, 1501-1516, doi:10.5194/bg-10-1501-2013, 2013.

Bond, T. C., Streets, D., Yarber, K. F., Nelson, S. M., Woo, J.H., and Klimont, Z.: A technology-based global inventory of black and organic carbon emissions from combustion, J. Geophys. Res., 109, D14203, doi:10.1029/2003JD003697, 2004.

Bowman, D. M. J. S., Balch, J. K., Artaxo, P., Bond, W. J., Carlson, J. M., Cochrane, M. A., D’Antonio, C. M., Defries, R. S., Doyle, J. C., Harrison, S. P., Johnston, F. H., Keeley, J. E., Krawchuk, M. A., Kull, C. A., Marston, J. B., Moritz, M. A., Prentice, I. C., Roos, C. I., Scott, A. C., Swetnam, T. W., van der Werf, G. R., and Pyne, S. J.: Fire in the Earth system, Science, 324, 481-484, 2009.

Chubarova, N., Nezval', Y., Sviridenkov, I., Smirnov, A., and Slutsker, I.: Smoke aerosol and its radiative effects during extreme fire event over Central Russia in summer 2010, Atmos. Meas. Tech., 5, 557-568, doi:10.5194/amt-5-557-2012, 2012.

Chuvieco, E., Giglio, L., and Justice, C.: Global characterization of fire activity: toward defining fire regimes from Earth observation data, Glob. Chang. Biol., 14, 1488-1502, 2008.

Friedl, M. A., Sulla-Menashe, D., Tan, B., Schneider, A., Ramankutty, N., Sibley, A., and Huang, X.: MODIS Collection 5 global land cover: Algorithm refinements and characterization of new datasets, Remote Sens. Environ., 114, 168-182, 2010.

Forster, P., Ramaswamy, V., Artaxo, P., Berntsen, T., Betts, R., Fahey, D. W., Haywood, J., Lean, J., Lowe, D. C., Myhre, G., Nganga, J., Prinn, R., Raga, G., Schulz, M., and Van Dorland, R.: Changes in Atmospheric Constituents and in Radiative Forcing, in: Climate Change 2007: The Physical Science Basis. Contribution of Working Group I to the Fourth Assessment Report of the Intergovernmental Panel on Climate Change, edited by: Solomon, S., Qin, D., Manning, M., Chen, Z., Marquis, M., Averyt, K. B., Tignor, M., and Miller, H. L., Cambridge University Press, Cambridge, United Kingdom and New York, NY, USA, 129-234, 2007.

Giglio, L., Loboda, T., Roy, D. P., Quayle, B., and Justice, C. O.: An active-fire based burned area mapping algorithm for the MODIS sensor, Remote Sens. Environ., 113, 408-420, 2009.

Govaerts, Y. M., Pereira, J. M., Pinty, B., and Mota, B.: Impact of fires on surface albedo dynamics over the African continent, J. Geophys. Res., 107, 4629, doi:10.1029/2002JD002388, 2002.

Gray, L. J., Beer, J., Geller, M., Haigh, J. D., Lockwood, M., Matthes, K., Cubasch, U., Fleitmann, D., Harrison, G., Hood, L., Luterbacher, J., Meehl, G. A., Shindell, D., van Geel, B., and White, W.: Solar Influences on Climate, Rev. Geophys., 48, RG4001, doi:10.1029/2009RG000282, 2010.

Holben, B. N., Smirnov, A., Eck, T. F., Slutsker, I., Abuhassan, N., Newcomb, W. W., Schafer, J. S., Tanre, D., Chatenet, B., and Lavenu, F.: An emerging ground-based aerosol climatology Aerosol optical depth from AERONET, J. Geophys. Res., 106, 12067-12097, 2001. 
Jin, Y. and Roy, D. P.: Fire-induced albedo change and its radiative forcing at the surface in northern Australia, Geophys. Res. Lett., 32, L13401, doi:10.1029/2005GL022822, 2005.

Jin, Y., Randerson, J. T., Goetz, S. J., Beck, P. S. A., Loranty, M. M., and Goulden, M. L.: The influence of burn severity on postfire vegetation recovery and albedo change during early succession in North American boreal forests, J. Geophys. Res., 117, G01036, doi:10.1029/2011JG001886, 2012a.

Jin, Y., Randerson, J. T., Goulden, M. L., and Goetz, S. J.: Postfire changes in net shortwave radiation along a latitudinal gradient in boreal North America, Geophys. Res. Lett., 39, L13403, doi:10.1029/2012GL051790, 2012b.

Ju, J., Roy, D. P., Shuai, Y., and Schaaf, C.: Development of an approach for generation of temporally complete daily nadir MODIS reflectance time series, Remote Sens. Environ., 114, 1-20, 2010.

Kalnay, E., Kanamitsu, M., Kistler, R., Collins, W., Deaven, D., Gandin, L., Iredell, M., Saha, S., White, G., Woollen, J., Zhu, Y., Leetmaa, A., Reynolds, R., Chelliah, M., Ebisuzaki, W., Higgins, W., Janowiak, J., Mo, K. C., Ropelewski, C., Wang, J., Jenne, R., and Joseph, D.: The NCEP/NCAR 40-Year Reanalysis Project, B. Am. Meteorol. Soc., 77, 437-471, 1996.

Lewis, S. L., Brando, P. M., Phillips, O.L., van der Heijden, G. M. F., and Nepstad, D.: The 2010 Amazon drought, Science, 331, 554, doi:10.1126/science.1200807, 2011.

Liang, S.: Narrowband to broadband conversions of land surface albedo I Algorithms, Remote Sens. Environ., 76, 213-238, 2001.

Lucht, W. and Lewis, P.: Theoretical noise sensitivity of BRDF and albedo retrieval from the EOS-MODIS and MISR sensors with respect to angular sampling, Int. J. Remote Sens., 21, 81-98, 2000.

Lucht, W., Schaaf, C. B., and Strahler, A. H.: An algorithm for the retrieval of albedo from space using semiempirical BRDF models, IEEE Trans. Geosci. Remote Sens., 38, 977-998, 2000.

MCD64A1 burned area product: ftp://fuoco.geog.umd.edu/db/ MCD64A1/, last access: 24 April 2014.

NCEP/NCAR dswrf at the surface: ftp:/ftp.cdc.noaa.gov/Datasets/ ncep.reanalysis.derived/surfacegauss/dswrf.sfc.mon.mean.nc, last access: 24 April 2014.

Pereira, J. M.: A comparative evaluation of NOAA/AVHRR vegetation indexes for burned surface detection and mapping, IEEE Trans. Geosci. Remote Sens., 37, 217-226, 1999.

Prentice, I. C., Baines, P. G., Scholze, M., and Wooster, M. J.: Fundamentals of climate change science, in: Understanding the Earth System: Global Change Science for Application, edited by: CornellS. E., Prentice, I. C., House, J. I., and Downy, C. J., Cambridge University Press, 39-71, 2012.
Ramaswamy, V., Boucher, O., Haigh, J. D., Hauglustaine, D., Haywood, J., Myhre, G., Nakajima, T., Shi, G. Y., and Solomon, S.: Radiative Forcing of Climate Change, in: Climate Change 2001: The Scientific Basis. Contribution of Working Group I to the Third Assessment Report of the Intergovernmental Panel on Climate Change, edited by: Houghton, J. T., Ding, Y., Griggs, D. J., Noguer, M., van der Linden, P. J., Dai, X., Maskell, K., and Johnson, C. A., Cambridge University Press, Cambridge, UK and New York, NY, USA, 349-416, 2001.

Schaaf, C. B., Gao, F., Strahler, A. H., Lucht, W., Li, X., Tsang, T., Strugnell, N. C., Zhange, X., Jin, Y., Muller, J. P., Lewis, P., Barnsley, M., Hobson, P., Disney, M., Roberts, G., Dunderdale, M., Doll, C., d'Entremont, R. P., Hu, B., Liang, S., Privett, J. L., and Roy, D.: First operational BRDF, albedo nadir reflectance products from MODIS, Rem. Sens. Environ., 83, 135-148, 2002.

Sheng, Y., Smith, L. C., MacDonald, G. M., Kremenetski, K. V., Frey, K. E., Velichko, A. A., Lee, M., Beilman, D. W., and Dubinin, P.: A high-resolution GIS-based inventory of the west Siberian peat carbon pool, Global Biogeochem. Cy., 18, GB3004, doi:10.1029/2003GB002190, 2004.

Shvidenko, A. Z., Shchepashchenko, D. G., Vaganov, E. A., Sukhinin, A. I., Maksyutov, S. S., McCallum, I., and Lakyda, I. P.: Impact of wildfire in Russia between 1998-2010 on ecosystems and the global carbon budget, Dokl. Earth Sci., 441, 16781682, 2011.

Stroppiana, D., Pinnock, S., Pereira, J. M., and Grégoire, J.-M.: Radiometric analysis of SPOT-VEGETATION images for burnt area detection in Northern Australia, Remote Sens. Environ., 82, 21-37, 2002.

Turquety, S., Logan, J. A., Jacob, D. J., Hudman, R. C., Leung, F. Y., Heald, C. L., Yantosca, R. M., Wu, S., Emmons, L. K., Edwards, D. P., and Sachse, G. W.: Inventory of boreal fire emissions for North America in 2004: Importance of peat burning and pyroconvective injection, J. Geophys. Res., 112, D12S03, doi:10.1029/2006JD007281, 2007.

Van der Werf, G. R., Randerson, J. T., Giglio, L., Collatz, G. J., Mu, M., Kasibhatla, P. S., Morton, D. C., DeFries, R. S., Jin, Y., and van Leeuwen, T. T.: Global fire emissions and the contribution of deforestation, savanna, forest, agricultural, and peat fires (19972009), Atmos. Chem. Phys., 10, 11707-11735, doi:10.5194/acp10-11707-2010, 2010. 